\title{
PENGARUH KOMPOS TANDAN KOSONG KELAPA SAWIT DAN ABU BOILER DI LAHAN GAMBUT TERHADAP PERTUMBUHAN DAN PRODUKSI SEMANGKA (Citrullus lanatus)
}

\section{The Effect of Application of Palm Oil Empty Bunches Compost and Boiler Ash in Peatlands on Growth and Yield of WaterMelon (Citrullus lanatus)}

\author{
Veranika, Nelvia, Al Ikhsan Amri \\ Department of Agrotechnology, Faculty of Agriculture, University of Riau \\ Email: Veranika_94@yahoo.com/087893314116 \\ [Diterima Desember 2017; Disetujui Maret 2018]
}

\begin{abstract}
The research aims to obtain a combination of doses of palm oil empty bunches compost (POEBC) and boiler ash to increase the growth and yield of watermelons on peatlands. The experiment was conducted in factorial form using Completely Randomized Design (CRD).The first factor was POEBC consisting of 4 levels $(0 ; 7,5 ; 10$ and 12,5 ton/ha) and the second factor is boiler ash consisting of 4 levels $(0 ; 2,5 ; 5$ and 7,5 ton/ha), and each combination was repeated 3 times. Parameters observed were plant length, stem diameter, flowering age, the weight of fruit per plant, and yield per plot $(15 \mathrm{~m} 2)$. The results showed that the combination of POEBC dosage 12,5 ton/ha and boiler ash dosage 7,5 ton/ha increased the plant length, stem diameter, the weight of fruit per plant $453 \%$, yield per plot $139 \%$ and flowering 8 days faster compared to control (without treatment).
\end{abstract}

Keywords: Watermelon, POEBC, Boiler Ash, Peatland.

\begin{abstract}
ABSTRAK
Penelitian ini bertujuan untuk memperoleh kombinasi dosis kompos tandan kosong kelapa sawit (POEBC) dan abu boiler untuk meningkatkan pertumbuhan dan hasil semangka di lahan gambut. Percobaan dilakukan dalam bentuk Vaktorial dengan menggunakan Rancangan Acak Lengkap (RAL). Faktor pertama adalah POEBC terdiri dari 4 level $(0 ; 7,5 ; 10$ dan 12,5 ton/ha) dan faktor kedua adalah abu boiler terdiri dari 4 level $(0 ; 2,5 ; 5$ dan 7,5 ton/ha), setiap kombinasi diulang 3 kali. Parameter yang diamati adalah panjang tanaman, diameter batang, umur berbunga, berat buah per tanaman, dan hasil per plot $\left(15 \mathrm{~m}^{2}\right)$. Hasil penelitian menunjukkan bahwa kombinasi dosis POEBC 12,5 ton/ha dan dosis abu boiler 7,5 ton/ha meningkatkan panjang tanaman, diameter batang, berat buah per tanaman $453 \%$, hasil per plot $139 \%$ dan berbunga 8 hari lebih cepat dibandingkan dengan kontrol (tanpa perawatan).
\end{abstract}

Kata Kunci: Semangka, POEBC, Abu Boiler, Lahan Gambut.

\section{PENDAHULUAN}

Perluasan areal tanam untuk budidaya semangka (Citrullus lanatus) dapat dilakukukan di lahan marjinal seperti lahan gambut karena cukup luas dan belum dimanfaatkan secara optimal. Tahun 2012 tercatat luas keseluruhan lahan gambut di Riau yaitu sekitar 4,9 juta hektar (BBPPLP, 2014).

Lahan gambut mempunyai berbagai kendala terutama kesuburan tanah yang rendah dicirikan antara lain $\mathrm{pH}$ rendah, kejenuhan basa rendah, memiliki kandungan unsur $\mathrm{N}, \mathrm{P}, \mathrm{K}, \mathrm{Ca}$, $\mathrm{Mg}$ yang rendah, memiliki kandungan unsur mikro (seperti $\mathrm{Cu}, \mathrm{Zn}$, Mn serta B) yang rendah, dan memiliki kapasitas tukar kation yang tinggi (Sasli, 2011).

Alternatif yang dapat dilakukan untuk memperbaiki kesuburan tanah gambut dengan cara pemberian kompos dan abu. Kompos mengandung unsur hara makro dan mikro lengkap meskipun dalam jumlah yang relatif kecil, dalam jangka panjang pemberian kompos dapat meningkatkan $\mathrm{pH}$ dan hasil pertanian 
(Setyorini et al., 2006). Puspitasari et al. (2013) menyatakan bahwa dengan penambahan kompos maka kapasitas jerapan dan kekuatan jerapan tanah gambut akan meningkatkan nilai kejenuhan basa, sehingga ketersediaan unsur hara didalam tanah akan meningkat seperti N, P dan K.

Salah satu jenis kompos yaitu kompos tandan kosong kelapa sawit (TKKS) yang merupakan limbah dari pabrik kelapa sawit yang ketersediaannya cukup banyak di Provinsi Riau. Ningtyas dan Lia (2010) melaporkan bahwa kompos TKKS mengandung unsur hara makro yaitu $14,5 \% \mathrm{C}$ Organik, $2,15 \% \mathrm{~N}$-Total, $1,54 \% \mathrm{P}_{2} \mathrm{O}_{5}, 0,15 \% \mathrm{~K}_{2} \mathrm{O}, \mathrm{pH}\left(\mathrm{H}_{2} 0\right) 6,32$ dan mengandung sedikit unsur mikro seperti $\mathrm{Cu}$, $\mathrm{Zn}, \mathrm{Mn}, \mathrm{Co}, \mathrm{Fe}, \mathrm{Bo}$, dan Mo.

Selain itu, untuk mengurangi pengaruh buruk asam-asam organik yang beracun dapat dilakukan dengan pemberian abu. Abu boiler memiliki kandungan kalium yang tinggi, serta dapat memperbaiki $\mathrm{pH}$ tanah masam dan meningkatkan ketersediaan unsur hara tanah sehingga abu boiler dinilai sebagai produk bernilai tinggi dan dianggap penting untuk membantu dalam meningkatkan pertumbuhan dan produksi tanaman (Pahan, 2006).

Abu boiler merupakan limbah padat pabrik kelapa sawit hasil dari sisa pembakaran cangkang dan serat kelapa sawit. Bahan bakar boiler terdiri dari TKKS dan cangkang kelapa sawit. Menurut Wahid (2009), unsur hara yang terkandung di dalam abu boiler kelapa sawit antara lain P 2,67\%, K 3,89\%, Mg 1,89\%, CaO $38,06 \%$, dan unsur mikro yaitu $\mathrm{Mn}, \mathrm{Zn}, \mathrm{Cu}, \mathrm{B}$, dan $\mathrm{Cl}$.

Penelitian mengenai penggunaan abu boiler dan kompos TKKS pada beberapa tanaman telah banyak dilakukan, seperti penelitian Alfianim (2015), yang menyatakan bahwa pemberian pupuk kalium dan campuran tandan kosong kelapa sawit dan abu boiler berpengaruh nyata terhadap umbi per rumpun dan berat segar umbi per plot pada bawang merah. Pemberian $120 \mathrm{~kg} \quad \mathrm{~K}_{2} \mathrm{O} / \mathrm{ha}$ dengan campuran kompos TKKS dan abu boiler 7,5 + 0,25 ton/ha merupakan dosis terbaik dalam meningkatkan tinggi tanaman $29,46 \mathrm{~cm}$, jumlah umbi per rumpun sampel 10,4 buah, diameter umbi per rumpun sampel $2,16 \mathrm{~cm}$, berat segar umbi/rumpun sampel $48 \mathrm{~g}$ dan berat segar umbi per plot $719 \mathrm{~g}$.
Penelitian ini bertujuan untuk mendapatkan kombinasi dosis kompos tandan kosong kelapa sawit dan abu boiler untuk meningkatkan pertumbuhan dan hasil semangka di lahan gambut.

\section{METODE PENELITIAN}

Penelitian dilaksanakan pada lahan gambut dengan tingkat kematangan saprik kedalaman gambut $90 \mathrm{~cm}$ di Kebun Percobaan Fakultas Pertanian Universitas Riau, Desa Rimbo Panjang, Kabupaten Kampar, Riau dari bulan Juli sampai Oktober 2016.

Bahan yang digunakan dalam penelitian adalah benih semangka Varietas New Dragon, kompos tandan kosong kelapa sawit, abu boiler, mulsa plastik hitam perak, pupuk urea, $\mathrm{KCl}$, TSP, Dithane M-45 dan Curacron 500 EC.

Alat yang digunakan dalam penelitian adalah cangkul, meteran, tali, gembor, timbangan, timbangan analitik dan alat tulis.

Penelitian dilaksanakan secara eksperimen dalam bentuk faktorial menggunakan Rancangan Acak Lengkap (RAL). Faktor pertama kompos TKKS terdiri dari 4 taraf $(0 ; 7,5 ; 10$ dan 12,5 ton/ha) dan faktor ke dua abu boiler terdiri dari 4 taraf $(0$; 2,$5 ; 5$ dan 7,5 ton $/$ ha), masing-masing kombinasi diulang 3 kali.

Pemberian kompos TKKS dan abu boiler dilakukan setelah pengolahan tanah. Kompos TKKS diberikan bersamaan dengan abu boiler dengan cara ditebar diantara lubang tanam dengan jarak $10 \mathrm{~cm}$ dari tanaman. Kemudian diaduk merata dan di inkubasi selama satu minggu. Pupuk urea, TSP, dan $\mathrm{KCl}$ masingmasing dosis $45 \mathrm{~kg} / \mathrm{ha}, 45 \mathrm{~kg} / \mathrm{ha}$, dan $45 \mathrm{~kg} / \mathrm{ha}$ diberikan 3 kali pada umur tanaman 3 hari setelah tanam, 20 hari dan 45 hari dengan dosis yang sama (3,2;3,2; dan 2,5 g/tanaman).

Bibit semangka yang telah berumur 14 hari siap ditanam di bedengan dengan jarak tanam $100 \mathrm{~cm} \times 100 \mathrm{~cm}$ dan jarak $50 \mathrm{~cm}$ dari tepi bedangan.

Parameter yang diamati adalah panjang tanaman, umur berbunga, diameter batang,berat buah per sampel, dan berat buah per plot. Data hasil pengamatan setiap parameter dianalisis menggunakan uji Duncan's New Multiple Range Test (DNMRT) pada taraf $5 \%$. 


\section{HASIL DAN PEMBAHASAN Panjang Tanaman}

Tabel 1 menunjukkan bahwa kombinasi kompos TKKS dosis 12,5 ton/ha dan abu boiler dosis 7,5 ton/ha meningkatkan panjang tanaman semangka tertinggi dibandingkan kombinasi lain, bila dibandingkan dengan kontrol terjadi peningkatan hampir 3 kalinya.

Hal ini dikarenakan kompos TKKS dan abu boiler mampu menyediakan unsur hara makro dan mikro dalam jumlah yang cukup dan seimbang di lahan gambut. Ningtyas dan Lia
(2010) melaporkan bahwa kompos TKKS mengandung unsur hara makro yaitu $14,5 \% \mathrm{C}$ Organik, 2,15\% N-Total, $1,54 \% \mathrm{P}_{2} \mathrm{O}_{5}, 0,15 \%$ $\mathrm{K}_{2} \mathrm{O}$, pH $\left(\mathrm{H}_{2} \mathrm{O}\right)$ 6,32 dan mengandung sedikit unsur mikro seperti $\mathrm{Cu}, \mathrm{Zn}, \mathrm{Mn}, \mathrm{Co}, \mathrm{Fe}$, Bo, dan Mo. Sedangkan menurut Wahid (2009), unsur hara yang terkandung di dalam abu boiler kelapa sawit antara lain P 2,67\%, K 3,89\%, Mg 1,89\%, $\mathrm{CaO} 38,06 \%$, dan unsur mikro yaitu $\mathrm{Mn}, \mathrm{Zn}$, $\mathrm{Cu}, \mathrm{B}$, dan $\mathrm{Cl}$.

Oleh sebab itu keduanya berperan meningkatkan ketersediaan hara secara langsung pada lahan gambut dan meningkatkan $\mathrm{pH}$ tanah.

Tabel 1. Panjang tanaman semangka $(\mathrm{cm})$ dengan pemberian kompos TKKS dan abuboiler

\begin{tabular}{ccccc}
\hline \multirow{2}{*}{$\begin{array}{c}\text { Kompos TKKS } \\
\text { (ton/ha) }\end{array}$} & \multicolumn{4}{c}{ Abu Boiler (ton/ha) } \\
\cline { 2 - 5 } & 0 & 2,5 & 5 & 7,5 \\
\hline 0,0 & $125,55 \mathrm{i}$ & $120,66 \mathrm{i}$ & $133,44 \mathrm{hi}$ & $147,55 \mathrm{gh}$ \\
7,5 & $150,55 \mathrm{gh}$ & $202,33 \mathrm{f}$ & $233,22 \mathrm{e}$ & $248,44 \mathrm{e}$ \\
10,0 & $163,22 \mathrm{~g}$ & $253,11 \mathrm{~d}$ & $280,66 \mathrm{~d}$ & $305,21 \mathrm{c}$ \\
12,5 & $165,66 \mathrm{~g}$ & $307,66 \mathrm{c}$ & $346,99 \mathrm{~b}$ & $374,44 \mathrm{a}$ \\
\hline
\end{tabular}

Angka-angka yang diikuti huruf kecil yang tidak sama pada baris yang sama adalah berbeda nyata menurut uji DNMRT pada taraf $5 \%$.

Ketersediaan hara meningkat maka proses fisiologis dan metobolisme tanaman juga meningkat sehingga berpengaruh pada proses fotosintesis yang berjalan lancar. Fotosintat yang dihasilkan pada proses fotosintesis akan dirombak kembali melalui proses respirasi dan menghasilkan energi yang diperlukan oleh sel untuk melakukan aktifitas seperti pembelahan dan pembesaran sel yang menyebabkan tanaman mencapai panjang maksimal.

Sarief (1985), menyatakan bahwa dengan tersedianya unsur hara dalam jumlah yang cukup pada saat pertumbuhan vegetatif, maka proses fotosintesis akan berjalan aktif, sehingga proses pembelahan, pemanjangan dan diferensiasi sel akan berjalan dengan lancar pula. Unsur $\mathrm{N}$ yang terdapat pada kompos TKKS juga mempunyai peranan penting dalam hal pertumbuhan dan perkembangan jaringan hidup. Hal ini sesuai dengan pendapat Lingga dan Marsono (2001), bahwa peranan unsur N adalah mempercepat pertumbuhan secara keseluruhan terutama batang dan daun.

Selain itu, kompos TKKS dan abu boiler dapat menambah ketersediaan unsur $\mathrm{P}$ yang dapat merangsang pertumbuhan dan perkembangan akar dan membentuk sistem perakaran yang baik sehingga meningkatkan kapasitas serapan dan kecepatan penyerapan unsur hara, membantu asimilasi dan respirasi sehingga pertumbuhan tanaman semakin baik.

Hasil penelitian Harbianto et al., (2015) menyatakan bahwa perlakuan kombinasi kompos TKKS 1,2 ton/ha dan abu boiler 150 $\mathrm{kg} / \mathrm{ha}$ menunjukkan tinggi tanaman yang tertinggi pada bawang merah yaitu $31,26 \mathrm{~cm}$ berbeda nyata dengan perlakuan kompos TKKS $0-0,3$ ton/ha dan abu boiler $0-100 \mathrm{~kg} / \mathrm{ha}$, namun berbeda tidak nyata dengan perlakuan lainnya. Hal ini disebabkan unsur hara yang terkandung pada kompos TKKS dan abu boiler dosis tertinggi tersedia lebih banyak bagi tanaman dibanding perlakuan lainnya, sehingga unsur hara dapat diserap tanaman dengan baik dari larutan tanaholeh akar tanaman. Kondisi ini mampu meningkatkan perkembangan sel untuk pertambahan tinggi tanaman bawang merah.

Unsur $\mathrm{K}$ juga berperan dalam meningkatkan aktivitas enzim dalam reaksi fotosintesis dan respirasi sehingga berdampak positif terhadap peningkatkan tinggi tanaman semangka. Menurut Hanafiah (2005), tanaman menyerap unsur $\mathrm{K}$ dalam bentuk ion $\mathrm{K}+$ yang berasal dari dekomposisi bahan organik yang terlarut dalam larutan tanah. Campuran kompos TKKS dan abu boiler mengandung humus yang 
dapat memacu pertumbuhan tanaman secara langsung karena dapat berfungsi sebagai hormon tanaman alami sehingga dapat memperbaiki penyerapan hara oleh akar tanaman, sebagai sumber $\mathrm{N}, \mathrm{P}$ dan $\mathrm{S}$ serta dapat meningkatkan kapasitas tukar kation sehingga mampu mengikat unsur-unsur yang bermuatan positif seperti $\mathrm{Ca}, \mathrm{Mg}$, dan $\mathrm{K}$. kapasitas tukar kation meningkat maka tanah akan mengikat lebih banyak hara dan membebaskan untuk pertumbuhan tanaman sehingga akan berdampak positif terhadap pertumbuhan vegetatif tanaman semangka.

\section{Diameter Batang}

Tabel 2 menunjukkan bahwa kombinasi kompos TKKS dosis 12,5 ton/ha dan abu boiler dosis 7,5 ton/ha meningkatkan diameter batang tanaman semangka dibandingkan kombinasi lain, yaitu terjadi peningkatan diameter batang hingga 2,24 kali dibanding kontrol.

Tabel 2. Diameter batang tanaman semangka $(\mathrm{cm})$ dengan pemberian kompos TKKS dan abu boiler

\begin{tabular}{ccccc}
\hline Kompos TKKS & \multicolumn{4}{c}{ Abu Boiler (ton/ha) } \\
\cline { 2 - 5 } (ton/ha) & 0 & 2,5 & 5 & 7,5 \\
\hline 0 & $0,57 \mathrm{i}$ & $0,59 \mathrm{i}$ & $0,61 \mathrm{i}$ & $0,68 \mathrm{i}$ \\
7,5 & $0,72 \mathrm{hi}$ & $1,11 \mathrm{f}$ & $1,23 \mathrm{ef}$ & $1,27 \mathrm{de}$ \\
10 & $0,86 \mathrm{gh}$ & $1,12 \mathrm{f}$ & $1,38 \mathrm{~cd}$ & $1,46 \mathrm{c}$ \\
12,5 & $0,91 \mathrm{~g}$ & $1,49 \mathrm{c}$ & $1,65 \mathrm{~b}$ & $1,85 \mathrm{a}$ \\
\hline
\end{tabular}

Angka-angka yang diikuti huruf kecil yang tidak sama pada baris yang sama adalah berbeda nyata menurut uji DNMRT pada taraf $5 \%$.

Hal ini disebabkan karena meningkatnya ketersediaan unsur hara yang diberikan melalui kompos TKKS dan abu boiler sehingga meningkatkan pertumbuhan tanaman secara optimal. Salah satunya adalah bertambahnya panjang tanaman seperti pada hasil sebelumnya yang hasil panjang tanaman meningkat sehingga berdampak pada diameter batang yang besar.

Proses metabolisme yang terjadi di dalam tubuh tanaman akan berjalan baik apabila kebutuhan unsur hara terpenuhi sehingga akan meningkatkan diameter batang semangka. Munawar (2011) menyatakan bahwa pertumbuhan dan hasil tanaman berhubungan erat dengan ketersediaan unsur hara yang diserap oleh tanaman yang digunakan dalam proses metabolisme tanaman. Dengan meningkatnya proses metabolisme tanaman akan berdampak positif dalam pembentukan diameter batang semangka.

Menurut Sutarta et al. (2005) kompos TKKS dan abu boiler sebagai pupuk alami antara lain meningkatkan unsur hara tanah, untuk memelihara kondisi tanah, serta meningkatkan kapasitas tukar kation, $\mathrm{pH}$ serta ketersediaan unsur hara seperti N,P,K, dan Mg. Ketersediaan hara dari kompos TKKS dan abu boiler semakin melengkapi kebutuhan tanaman di lahan gambut sehingga pertumbuhan tanaman semakin baik yang berdampak pada diameter batang yang semakinbesar.
Rendahnya $\mathrm{P}$ dan $\mathrm{K}$ pada tanah gambut karena lahan gambut merupakan hasil akumulasi bahan organik yang belum terdekomposisi secara sempurna dan menyebabkan lahan gambut miskin unsur hara $\mathrm{P}$ dan $\mathrm{K}$. Oleh sebab itu, unsur hara $\mathrm{P}$ dan $\mathrm{K}$ pada tanah gambut sangat diperlukan terhadap perubahan kesuburan tanah.

Unsur $\mathrm{P}$ yang terdapat pada kompos TKKS dan abu boiler berfungsi untuk pembelahan sel tanaman dan memperbesar jaringan sel sehingga berpengaruh pada pertambahan diameter batang. Menurut Gardner et al. (1991) unsur $\mathrm{N}, \mathrm{P}, \mathrm{K}$ sangat berperan dalam meningkatkan pertumbuhan vegetatif tanaman. Unsur $\mathrm{N}, \mathrm{P}$ dan $\mathrm{K}$ tersebut sangat penting bagi tanaman karena berperan dalam pembentukan asam amino, protein, asam nukleat dan karbohidrat. Karbohidrat sederhana yang dihasilkan dari proses fotosintesis akan digunakan untuk proses respirasi menghasilkan ATP, membentuk lipid, asam nukleat dan protein yang selanjutnya digunakan untuk membentuk batang, daun, akar dan jaringan baru.

\section{Umur Berbunga}

Tabel 3 menunjukkan bahwa kombinasi kompos TKKS dosis 12,5 ton/ha dan abu boiler dosis 7,5 ton/hamenghasilkan umur berbunga tanaman semangka tercepat dibandingkan 
kombinasi lain, tanaman berbunga 8 hari lebih cepat dibanding kontrol.

Hal tersebut dikarenakan pemberian kompos TKKS dan abu boiler dalam jumlah cukup dapat menambah ketersediaan unsur
$\mathrm{N}, \mathrm{P}$, dan $\mathrm{K}$ di lahan gambut. Kebutuhan unsur hara yang terpenuhi maka akan berdampak pada pertumbuhan tanaman yang baik sehingga berpengaruh pada umur berbunga yang semakin cepat.

Tabel 3. Umur berbunga tanaman semangka(HST) dengan pemberian kompos TKKS dan abu boiler

\begin{tabular}{ccccc}
\hline Kompos TKKS & \multicolumn{4}{c}{ Abu Boiler (ton/ha) } \\
\cline { 2 - 5 } (ton/ha) & 0 & 2,5 & 5 & 7,5 \\
\hline 0 & $0,57 \mathrm{i}$ & $0,59 \mathrm{i}$ & $0,61 \mathrm{i}$ & $0,68 \mathrm{i}$ \\
7,5 & $0,72 \mathrm{hi}$ & $1,11 \mathrm{f}$ & $1,23 \mathrm{ef}$ & $1,27 \mathrm{de}$ \\
10 & $0,86 \mathrm{gh}$ & $1,12 \mathrm{f}$ & $1,38 \mathrm{~cd}$ & $1,46 \mathrm{c}$ \\
12,5 & $0,91 \mathrm{~g}$ & $1,49 \mathrm{c}$ & $1,65 \mathrm{~b}$ & $1,85 \mathrm{a}$ \\
\hline
\end{tabular}

Angka-angka yang diikuti huruf kecil yang tidak sama pada baris yang sama adalah berbeda nyata menurut uji DNMRT pada taraf $5 \%$.

Menurut Dwidjosaputra (1997) suatu tanaman akan tumbuh dengan baik, bila unsur hara yang dibutuhkan cukup tersedia dalam bentuk yang mudah diserap oleh perakaran tanaman, sehingga semakin baik pertumbuhan tanaman akan mempercepat proses pembungaan.

Idwar et al. (2013) menyatakan bahwa perlakuan $\mathrm{H}(1,45 \mathrm{~kg}$ TKKS $+145 \mathrm{~g}$ abu boiler $+2,9$ g Trichoderma) per plot cenderung mempercepat umur berbunga pada tanaman kedelai.

Kandungan yang terdapat dalam kompos TKKS dan abu boiler diantaranya unsur $\mathrm{P}$ dan $\mathrm{K}$ yang berfungsi sebagai salah satu unsur yang dibutuhkan tanaman pada masa pertumbuhan generatif. Unsur P berperan untuk merangsang proses pembungaan. Kebutuhan tanaman terhadap unsur $\mathrm{P}$ meningkat tinggi ketika tanaman akan berbunga. Semakin tinggi takaran kompos TKKS dan abu boiler yang diberikan maka semakin tinggi sumbangan unsur $P$. Menurut Lingga dan Marsono (2001) unsur P berfungsi sebagai bahan mentah untuk pembentukan sejumlah protein tertentu, membantu asimilasi dan pernafasan, mempercepat pembungaan dan pemasakan biji.

Sobir dan Siregar (2010) menyatakan bahwa unsur $\mathrm{K}$ (kalium) mendukung pertumbuhan tanaman, pembungaan dan pembentukan buah. Semua unsur tersebut dapat terpenuhi dengan adanya penambahan abu boiler dan kompos TKKS sehingga berpengaruh pada proses pembungaan yang lebih cepat.

\section{Berat Buah Semangka Per Sampel}

Tabel 4 menunjukkan bahwa kombinasi kompos TKKS dosis 12,5 ton/ha dan abu boiler dosis 7,5 ton/ha meningkatkan berat buah semangka tertinggi dibandingkan kombinasi lain, dibandingkan dengan kontrol terjadi peningkatan berat buah semangka sebesar 453 $\%$.

Hal ini menunjukkan bahwa semakin besar dosis kompos TKKS dan abu boiler yang diberikan maka semakin besar kontribusinya menyediakan hara yang dibutuhkan tanaman untuk pengisian buah sehingga berpengah terhadap berat buah semangka.l

Tabel 4. Berat buah semangka per sampel (kg) dengan pemberian kompos TKKS dan abu boiler.

\begin{tabular}{ccccc}
\hline \multirow{2}{*}{$\begin{array}{c}\text { Kompos TKKS } \\
\text { (ton/ha) }\end{array}$} & \multicolumn{4}{c}{ Abu Boiler (ton/ha) } \\
\cline { 2 - 5 } & 0 & 2,5 & 5 & 7,5 \\
\hline 0 & $0,65 \mathrm{~g}$ & $0,89 \mathrm{fg}$ & $0,95 \mathrm{fg}$ & $1,25 \mathrm{fg}$ \\
7,5 & $0,80 \mathrm{fg}$ & $1,06 \mathrm{fg}$ & $1,12 \mathrm{fg}$ & $1,42 \mathrm{ef}$ \\
10 & $0,96 \mathrm{fg}$ & $1,93 \mathrm{de}$ & $1,98 \mathrm{cde}$ & $2,55 \mathrm{bc}$ \\
12,5 & $1,00 \mathrm{fg}$ & $2,30 \mathrm{~cd}$ & $2,96 \mathrm{~b}$ & $3,60 \mathrm{a}$ \\
\hline
\end{tabular}

Angka-angka yang diikuti huruf kecil yang tidak sama pada baris yang sama adalah berbeda nyata menurut uji DNMRT pada taraf $5 \%$.

Ketersediaan unsur hara yang optimal sangat mempengaruhi berat buah semangka yang dihasilkan. Unsur hara yang diperoleh tanaman dimanfaatkan untuk membentuk karbohidrat, protein dan lemak yang disimpan, 
maka akan semakin besar buah dan berpengaruh padaberat buah semangka. Menurut Winarso (2005), jika unsur hara dalam keadaan cukup maka biosintesis dapat berjalan lancar, sehingga karbohidrat yang dihasilkan akan semakin banyak dan dapat disimpan sebagai cadangan makanan, dengan demikian timbunan karbohidrat ini akan mengakibatkan terjadinya peningkatan berat buah.

Hasil penelitian La ode safuan et al. (2012) menyatakan bahwa dosis bahan organik yang optimal untuk tanaman melon adalah 12,25 ton.ha-1, pada dosis tersebut akan menghasilkan buah melon seberat $1,2 \mathrm{~kg}$ atau $2,4 \mathrm{~kg} /$ pohon atau 50,40 ton.ha-1. Hasil penelitian Nelvia et al. (2012), dengan melakukan penanaman kedelai pada lahan gambut yang diberi pupuk kompos TKKS dengan dosis 10-15 ton/ha mampu meningkatkan bintil akar efektif, persentase polong bernas, serta bobot biji kering, karena hasil analisis TKKS yang digunakan mengandung asam humat dan fulfat, kaya

gugus-gugus fungsionail/tapak reaktif yang dapat berkondensasi dengan asam-asam fenolat dari gambut membentuk humus.

Tersedianya unsur $\mathrm{P}$ dan $\mathrm{K}$ yang cukuppada kompos TKKS dan abu boiler memberikan respon yang positif terhadap berat buah semangka. Unsur $\mathrm{P}$ berfungsi sebagai penyimpan dan transfer energi untuk aktifitas metabolisme tanaman sehingga dapat menambah berat buah semangka. Hal ini berkaitan dengan fotosisintesis tanaman yang dapat menghasilkan fotosintat sebagai penyusun karbohidrat, lemak, protein, mineral dan vitamin akan ditraslokasikan kebagian peyimpanan buah yang dipengaruhi ketersedian $\mathrm{N}, \mathrm{P}$ dan $\mathrm{K}$ di dalam tanah.

Salisbury dan Ross (1995) menyatakan bahwa penyerapan $\mathrm{K}$ mempengaruhi kegiatan fotosintesis karena $\mathrm{K}$ mempengaruhi aktivitas enzim. Apabila aktivitas enzim terhambat, maka fotosintesis akan terhambat pula sehingga mengurangi translokasi karbohidarat dari daun ke buah. Sebagai akibatnya terjadi penurunan hasil tanaman dalam bentuk bobot atau kuantitas hasil.

Hal ini sesuai dengan Rinsema (1993) yang menyatakan bahwa pada fase reproduktif pertumbuhan berat buah menuntut jumlah hara makro yang banyak seperti nitrogen, fosfor dan kalium sehingga berat buah semakin meningkat.

\section{Hasil Buah Semangka Per Plot}

Tabel 5.menunjukkan bahwa kombinasi kompos TKKS dosis 12,5 ton/ha dan abu boiler dosis 7,5 ton/ha meningkatkan hasil buah semangka per plot tertinggi dibandingkan kombinasi lain, dibandingkan dengan kontrol terjadi peningkatan hasil buah semangka sebesar $139 \%$.

Hal ini disebabkan karena pemberian kompos TKKS dan abu boiler dosis lebih tinggi dapat menyediakan hara tanaman lebih banyak, meningkatkan $\mathrm{pH}$ tanah, dan juga kapasitas tukar kation (KTK) di dalam tanah. Menurut Wahid (2009), unsur hara yang terkandung di dalam abu boiler kelapa sawit antara lain $\mathrm{P}$ 2,67\%, K 3,89\%, Mg 1,89\%, $\mathrm{CaO} 38,06 \%$, dan unsur mikro yaitu $\mathrm{Mn}, \mathrm{Zn}, \mathrm{Cu}, \mathrm{B}$, dan $\mathrm{Cl}$. Peningkatan $\mathrm{pH}$ tersebut diduga karena tingginya kandungan $\mathrm{CaO}$ dalam abu boiler dimana bereaksi secara cepat dengan air. Reaksi $\mathrm{CaO}$ dengan air membentuk $\mathrm{Ca}(\mathrm{OH})_{2}$ yang selanjutnya terurai menjadi ion $\mathrm{Ca}^{2+}$ dan $\mathrm{OH}^{-}$. Ion $\mathrm{OH}^{-}+\mathrm{H}^{+} \rightarrow \mathrm{H} 2 \mathrm{O}$ sehingga meningkatkan $\mathrm{pH}$ tanah.

$\mathrm{pH}$ tanah meningkat maka kesuburan tanah juga meningkat sehingga kebutuhan hara terpenuhi serta memberikan pengaruh yang baik terhadap pertumbuhan tanaman. Pertumbuhan tanaman yang baik menyebabkan proses fotosintesis berjalan lancar sehingga karbohidrat yang dihasilkan pada proses fotosintesis ditraslokasikan kebagian peyimpanan buah menyebabkan terjadi pembentukan buah yang semakin baik sehingga hasil buah semangka meningkat.

Wardati et al., (2007) menyatakan bahwa abu serbuk gergaji yang diberikan pada tanah gambut untuk penanaman bawang sekali masa produksi dapat meningkatkan $\mathrm{pH}$ dari $3.75 \mathrm{ke}$ 5.3. Hasil penelitian Arifin dan Nazemi (2002) menjelaskan bahwa pemberian berbagai jenis abu yakni abu sekam, abu serbuk gergaji dan abu gambut dengan kandungan $\mathrm{K} 0.96 \mathrm{me} / 100 \mathrm{~g}$, telah mampu meningkatkan produksi kedelai dan jagung di lahan gambut, karena abu dapat mensubsitusi pupuk $\mathrm{K}$ dan meningkatkan ketersediaannya dalam tanah.

Unsur $\mathrm{K}$ yang terdapat pada kompos TKKS dan abu boiler berperan sebagai aktivator enzim dalam reaksi-reaksi fotosintesis dan respirasi (Lakitan, 2000). Peningkatan unsur K mampu menyediakan unsur hara yang cukup untuk pembentukkan buah yang banyak sehingga meningkatkan hasil buah semangka. 
Unsur $\mathrm{P}$ salah satu unsur yang dibutuhkan tanaman pada masa pertumbuhan generatif. Unsur P terdapat dalam substansi organik yang penting bagi tanaman dalam inti sel, sehingga unsur P banyak terdapat di dalam buah atau biji dan bagian tanaman muda. Siagian (2011) menyatakan unsur $\mathrm{P}$ dapat meningkatkan perkembangan akar yang kemudian dapat meningkatkan kadar P itu sendiri dalam tanaman yang akan diikuti dengan meningkatnya serapan unsur hara yang lain sehingga fotosintesis juga meningkat, dengan demikian fotosintat yang dihasilkan juga besar sehingga berpengaruh pada hasil buah semangka yang besar.

Tabel 5.Hasil buah semangka per plot(kg) dengan pemberian kompos TKKS dan abu boiler

\begin{tabular}{ccccc}
\hline \multirow{2}{*}{$\begin{array}{c}\text { Kompos TKKS } \\
\text { (ton/ha) }\end{array}$} & \multicolumn{4}{c}{ Abu Boiler (ton/ha) } \\
\cline { 2 - 5 } & 0 & 2,5 & 5 & 7,5 \\
\hline 0 & $2,00 \mathrm{~g}$ & $4,03 \mathrm{f}$ & $4,50 \mathrm{f}$ & $5,00 \mathrm{f}$ \\
7,5 & $3,63 \mathrm{f}$ & $6,56 \mathrm{f}$ & $5,36 \mathrm{f}$ & $9,90 \mathrm{e}$ \\
10 & $4,80 \mathrm{f}$ & $11,13 \mathrm{de}$ & $11,23 \mathrm{de}$ & $17,46 \mathrm{bc}$ \\
12,5 & $5,70 \mathrm{f}$ & $14,36 \mathrm{~cd}$ & $20,40 \mathrm{~b}$ & $29,95 \mathrm{a}$ \\
\hline
\end{tabular}

Angka-angka yang diikuti huruf kecil yang tidak sama pada baris yang sama adalah berbeda nyata menurut uji DNMRT pada taraf $5 \%$.

Unsur $\mathrm{P}$ dan $\mathrm{K}$ ini sangat baik dalam pembentukan buah pada tanaman semangka. Sesuai dengan pendapat Lingga (2001) yang menyatakan bahwa $\mathrm{P}$ dapat mempercepat penuaan buah serta meningkatkan hasil buah. Bila tanaman kekurangan unsur $\mathrm{P}$ maka metabolisme tanaman akan terganggu, terutama transfer energi dan proses fotosintesis yang berpengaruh pada proses pembentukan buah sehingga mempengaruhi ukuran buah yang berdampak pada hasil buah semangka yang rendah. Jika kekurangan unsur $\mathrm{P}$ dan $\mathrm{K}$ maka dapat menyebabkan kematangan buah terlambat dan ukuran buah menjadi kecil sehingga berdampak pada hasil buah semangka (Novizan, 2002).

Nurlenawati, Asmanur dan Nimih (2010) juga menyatakan bahwa produksi tanaman yang optimum dapat dicapai apabila jumlah dan macam unsur hara di dalam tanah bagi pertumbuhan tanaman berada dalam keadaan cukup, seimbang dan tersedia sesuai kebutuhan tanaman.

\section{KESIMPULAN}

Dari hasil penelitian pengaruh kompos TKKS dan abu boiler di lahan gambut terhadap pertumbuhan dan produksi semangka (Citrullus lanatus) dapat disimpulkan sebagai berikut :

kombinasi kompos TKKS dosis 12,5 ton/ha dan abu boiler dosis 7,5 ton/ha meningkatkan panjang tanaman 3 kali, diameter batang 4 kali, berat buah dan hasil semangka per plot berturut-turut sebesar $453 \%$ dan $139 \%$ dibandingkan kontrol (tanpa perlakuan) dengan masa pembungaan 8 hari lebih cepat.

\section{DAFTAR PUSTAKA}

Alfianim, D.F. 2015. Pengaruh Pupuk Kalium dan Campuran Kompos Tandan Kosong Kelapa Sawit dengan Abu Boiler terhadap Pertumbuhan dan Produksi Tanaman Bawang Merah (Allium Ascalonicum L.) Skripsi (Tidak dipulikasikan). Fakultas Pertanian Universitas Riau. Pekanbaru

Arifin, H.M.Z dan D. Nazemi. 2002. Kemampuan Subsitusi Bahan Amelioran Organik terhadap Pupuk Anorganik dalam Menyediakan K untuk Meningkatkan Hasil Jagung dan Kedelai di Lahan Gambut. Prosiding Seminar Nasional Pertanian Organik. Kerjasama Faperta UPN dengan CV. Cipta Tani Makmur. Yogyakarta.

(BBPPLP) Balai Besar Penelitian Dan Pengembangan Sumber daya Lahan Pertanian, Badan Penelitian Dan Pengembangan Pertanian, Kementerian Pertanian. 2011. Peta Lahan Gambut Indonesia Skala 1:250.000 Jakarta: Kementerian Pertanian.

Dwidjosaputra. 1997. Pengantar Fisiologi Tumbuhan. PT. Gramedia. Jakarta.

Gardner F. P., Pearce, dan R.L.Mitchel. 1991. Fisiologi Tanaman Budidaya. UI Press. Jakarta.

Harbianto, G., Armaini dan Idwar. 2015. Pengaruh Kompos TKKS dan Abu Boiler Kelapa Sawit terhadap Pertumbuhan dan 
Produksi Tanaman Bawang Merah (Allium ascalonicum L.). Jurnal agroteknologi Vol. 2 (2). Universitas Riau. Pekanbaru

Hanafiah K.A. 2005. Dasar-dasar Ilmu Tanah.Penerbit PT. Raja Grafindo Persada. Jakarta

Idwar, Nelvia dan R. Arianci. 2014. Pengaruh Campuran Kompos Tandan Kosong Kelapa Sawit, Abu Boiler dan Trichoderma Terhadap Pertanaman Kedelai pada Sela Tegakan Kelapa Sawit yang Telah Menghasilkan di Lahan Gambut. Jurnal Teknobiologi, Volume 1: 21-29.

Lakitan, B. 2000. Dasar - Dasar Fisiologi Tumbuhan. Raja Grafindo Persada. Jakarta

La Ode Safuan dan Andi Bahrun. 2012. Pengaruh Bahan Organik dan Pupuk Kalium terhadap Pertumbuhan dan Produksi Tanaman Melon (Cucumis melo L.). Jurnal Agroteknologi Fakultas Pertanian. Vol. 2 (2) Universitas Haluoleo, Kendari

Lingga dan Marsono. 2001. Petunjuk Penggunaan Pupuk. Penebar Swadaya. Jakarta.

Munawar, A. 2011.Kesuburan Tanaman dan Nutrisi Tanaman.IPB Press. Bogor.

Nelvia, Island dan D.F. Sihaan. 2012. Pertumbuhan dan Produksi Tanaman Kedelai sebagai Tanaman Sela di Kebun Kelapa Sawit pada Lahan Gambut yang Diaplikasi Kompos Tandan Kosong Kelapa Sawit. Prosiding Seminar Nasional Bidang Ilmu-Ilmu Pertanian BKS-PTN Wilayah Barat. Medan

Ningtyas, V. A. dan Lia, Y. A. 2010. Pemanfaatan Tandan Kosong Kelapa Sawit Sisa Media Jamur Merah (Volvarella volvaceae) sebagai Pupuk Organik dengan Penambahan Aktivator Effective Microorganisme EM-4. Skripsi. Fakultas Teknik Kimia. Institut Teknologi Surabaya. Surabaya.

Novizan. 2002. Petunjuk Pemupukan yang Efektif. Agromedia Pustaka. Jakarta.

Nurlenawati, N., Asmanur Jannah dan Nimih. 2010. Respon Pertumbuhan dan Hasil Tanaman Cabai Merah Varietas Prabu terhadap Berbagai Dosis Pupuk Fosfat dan Bokashi Jerami Limbah Jamur Merang. Jurnal AGRIKA, volume 4 (1): 9-20.
Pahan. I. 2006. Panduan Lengkap Kelapa Sawit Manajemen Agribisnis dari Hulu hingga Hilir. Cetakan kedua. Penebar Swadya. Jakarta.

P., Riza L., dan Mukarlina. 2013. Pertumbuhan Tanaman Pakchoy (Brassica chinensis L.) dengan Pemberian Kompos Alang-Alang (Imperata cylindrica (L.) Beauv) pada Tanah Gambut. Program Studi Biologi. Fakultas MIPA. Universitas Tanjungpura. Jurnal Protobiont 2013, Vol 2 (2): $44-48$ (Hal. 40,41).

Rinsema, W. 1993.Pupuk dan Pemupukan. Bhatara Karya Aksara. Jakarta.

Salisbury F.B dan C.W.Ross. 1995. Fisiologi Tumbuhan. Jilid 1. ITB. Bandung.

Sarief.S. 1985. Kesuburan dan Pemupukan Tanah Pertanian. Pustaka Buana. Bandung.

Sasli, I. 2011. Karakteristik Gambut dengan Berbagai Bahan Amelioran dan Pengaruhnya terhadap Sifat Fisik dan Kimia Guna Mendukung Produktivitas Lahan Gambut. Jurnal agrovigor. 4(1) : 42-50.

Setyorini, D., S. Saraswati dan A. Koesma. 2006. Pupuk Organik dan Pupuk Hayati.Laporan Proyek Penelitian Program Pengembangan Agribisnis. Balai Penelitian Tanah. Bogor. 11 hal

Siagian, M. 2011. Aplikasi beberapa Dosis Tricho Kompos Alang-Alang terhadap Pertumbuhan dan Produksi Tanaman Kedelai. Skripsi Fakultas Pertanian Universitas Riau Pekanbaru. (Tidak dipublikasikan).

Sobir dan Siregar.2010. Budi Daya Melon Unggul.Gramedia. Jakarta.

Sutarta S. dan Erwinsyah. 2005. Pengaruh Kompos Tandan Kosong Kelapa Sawit terhadap Sifat Tanah dan Pertumbuhan Tanaman. Jurnal Penelitian Kelapa Sawit Vol 8 (2). PPKS. Medan.

Wahid. 2009. Peningkatan Efisiensi Pupuk Nitrogen, Pospor, Kalium pada Padi Sawah. Jurnal Litbang Pertanian.

Wardati, Murniati, Mulyanto.Y. 2007. Abu Serbuk Gergaji sebagai Amelioran Lahan Gambut untuk Produksi Bawang Merah. Jurnal Penelitian Media Informasidan Komunikasi Ilmia. XVI(1). Lembaga PenelitianUniversitas Riau. Pekanbaru

Winarso, S. 2005. Kesuburan Tanah, Dasar Kesehatan dan Kualitas Tanah. Gramedia.Yogyakarta. 